\title{
Universidad, ciencia y contexto para la calidad académica: Una relación indispensable en los procesos investigativos
}

\author{
PhD. Rebeca Castellanos Gómez \\ Universidad Católica de Cuenca, UCACUE \\ rebeca.castellanos@ucacue.edu.ec \\ Cuenca, Ecuador \\ https://orcid.org/0000-0001-9873-128X
}

\section{Editorial}

La calidad académica en las universidades, entendida desde la docencia, investigación y vinculación, lleva implícitos los cuatro principios o características planteadas por la Organización de las Naciones Unidas (ONU) en el Pacto Internacional de Derechos Económicos, Sociales y Culturales (ICESCR, 1966), estos son: Asequibilidad (disponibilidad), Accesibilidad, Adaptabilidad y Aceptabilidad "4 A" (pág. 1-10); precisados por Tomasesvky (2004): relatora de las Naciones Unidas, expresa que estas características o principios se refieren al derecho de las personas a y en una educación de calidad y a la obligación de los Estados miembros del Pacto, a ofrecerla; en este caso, nos referimos a la educación superior (pág. 378). En términos generales, los cuatro principios funcionan interrelacionadamente entre las tres funciones sustantivas y transversalmente en toda la universidad, a fin de fomentar la calidad académica. Esta calidad se refiere a que la oferta académica de educación (carreras, programas, proyectos de investigación y vinculación, educación continua entre otros) sea pertinente a las necesidades de los contextos, al avance de la ciencia, a los planes de desarrollo del país, así como a las características y estilos de aprendizaje de los estudiantes, entre otras variables que la contemplan.

En el caso ecuatoriano, Ley Orgánica de Educación Superior (LOES, 2010a): expresa que desde las instituciones que rigen la educación superior en el país, se han realizado intentos para garantizar dicha calidad, para fomentar la vinculación con la sociedad y la investigación en busca del 
desarrollo de la matriz cognitiva (arts. 350-351). Así, la propia Ley Orgánica de Educación Superior (LOES, 2010b): establece un articulado especial para el tema de la pertinencia, en el cual se especifica su significado y la consideración que las universidades deben tener para su oferta (art. 107).

En cuanto al tema investigativo, el Reglamento de Régimen Académico (RRA, 2019), expedido por el Consejo de Educación Superior (CES), destaca la trascendencia de los procesos investigativos y su obligatoriedad en la oferta académica. Por una parte, le da a la investigación un carácter institucional dentro de las funciones sustantivas y la concibe como: "(...) una labor creativa, sistemática y sistémica, fundamentada en debates epistemológicos y necesidades del entorno que potencia los conocimientos y saberes científicos, ancestrales e interculturales (...)" (art. 4); en el literal b; por otra parte, desarrolla ampliamente el tema de Investigación Formativa, y la define en términos de "un proceso de uso y generación de conocimiento caracterizado por la aplicación de métodos convencionales de investigación, la innovación, el análisis y la validación entre pares produciendo, generalmente, conocimiento de pertinencia y validez local, nacional y/o internacional (...)" (art. 39). Esta consideración en el RRA, conlleva la obligatoriedad de la formación investigativa desde pregrado.

Como puede observarse, es reiterativo el tema de la pertinencia, ahora referida a la generación y aplicación de conocimientos. Es en este aspecto que queremos mencionar, brevemente, la experiencia de la Universidad Católica de Cuenca (UCACUE), la cual ha abrazado los Principios de calidad "4 A" de la educación superior de la Organización de las Naciones Unidas para la Educación, la Ciencia y la Cultura (UNESCO) y ha realizado un trabajo importante para orientar su pertinencia académica de acuerdo con las necesidades de los contextos y avances de la ciencia.

En este orden y en el marco de un proceso de evaluación curricular aplicado a sus 45 careras de pregrado en sus siete (07) Unidades Académicas 
(en todas sus sedes y extensiones), la UCACUE realizó 39 grupos focales con instituciones y empresas (76 del sector público y 64 del privado, para un total de 140 instituciones) en una investigación sin precedentes en la universidad. La técnica de focus group aplicada permitió, entre otras cosas, recoger información trascendental para el ajuste de la pertinencia (en atención a los principios de Asequibilidad, Adaptabilidad y Aceptabilidad) y la determinación de necesidades investigativas, tanto en el desarrollo de competencias investigativas en los estudiantes, como en aspectos puntuales a ser investigados para solucionar problemas de la sociedad que requieren de nuevos conocimientos científicos de carácter teórico y metodológico. El trabajo de análisis en las carreras, disciplinas y subdisciplinas aún continúa dada la riqueza de la información obtenida.

Dentro de los resultados surgió lo referido a las competencias investigativas de los estudiantes, allí se destacaron varios elementos de necesaria intervención: capacidad de observación y análisis, vinculación de la teoría con la práctica, lectura comprensiva y crítica, pensamiento crítico, razonamiento lógico, creatividad, iniciativa. Igualmente, llamó la atención un aspecto surgido tanto en las competencias como en la naturaleza de los problemas a investigar, nos referimos al abordaje interdisciplinario de los fenómenos. Podemos afirmar que en un $80 \%$ de los grupos focales realizados, los actores del contexto participantes informaron sobre la necesidad de diseñar y ejecutar investigaciones, proyectos de vinculación y hasta la práctica preprofesional, desde una perspectiva interdisciplinaria dado que las soluciones propuestas desde una única disciplina han sido parciales y no integrales.

Fueron interesantes los resultados obtenidos en cada sede y extensión en cuanto a las generalidades y particularidades encontradas en una misma carrera ofertada en contextos distintos. Por ejemplo, en el caso de salud, en Cañar se necesita intervención urgente en temas mortalidad infantil y 
problemas gastrointestinales en comunidades rurales e indígenas; en Macas es apremiante la realización de investigaciones referidas a la presencia de VIH en la población Shuar, lo que está causando una alta tasa de mortalidad; por su parte, en Cuenca surge el tema de enfermedades infantiles (que habían sido erradicadas) producto de la inmigración de familias provenientes de otros países. En todos estos casos se solicitan proyectos de investigación y propuestas realizadas desde equipos interdisciplinarios con presencia de médicos, enfermeras, antropólogos, psicólogos, trabajadores sociales y educadores. Para el Observatorio de los Derecho de la Niñez y la Adolescencia (2012): "en el contexto social ecuatoriano, la educación es una necesidad para formar individuos con mayores capacidades para realizar sus proyectos personales y mejorar sus condiciones vitales" (pág. 224).

De estos resultados es posible inferir que, en cuanto a la pertinencia ya mencionada, la relación entre la universidad y los contextos se convierte en una necesidad, ya no es posible que la universidad esté desvinculada de las necesidades del entorno. De otro lado, en cuanto a los procesos investigativos, las voces consultadas nos reclaman una pertinencia fundamental, pero, necesariamente, acompañada de abordajes interdisciplinarios que den cuenta de la complejidad de los fenómenos a fin de conocer profundamente sus causas y generar vías de solución adecuadas.

Con este panorama como telón de fondo, celebramos la edición de este número de la revista y lo celebramos por que se ha orientado a difundir resultados de experiencias investigativas que apuntan a la consecución de la calidad planteada por la UNESCO, a la pertinencia que nos plantea la LOES y a las exigencias investigativas en la formación formuladas en el Reglamento de Régimen Académico, así como a la interdisciplinariedad y la relación con los contextos que nos reclaman los actores de los grupos focales trabajados en la UCACUE. En este sentido, el rol de las revistas científicas en la difusión de los conocimientos contribuye grandemente con el avance de una ciencia 
con carácter global/local y con conciencia social y ambiental.

Se publican en este número artículos referidos a la transformación social desde el trabajo investigativo de las universidades, el rol del profesor en el servicio comunitario, Líneas de investigación y gestión del conocimiento (este último absolutamente necesario para poder dar respuesta oportuna y pertinente a las necesidades de los contextos y de las Políticas del país), el desarrollo de la ciencia hacia su concepción desde la complejidad. Son estos temas directamente relacionados con lo aquí descrito. Por otra parte, hay artículos de interés para el logro de la calidad de la educación de acuerdo con los cuatro Principios de la UNESCO, como los referidos al rol del docente universitario, al uso de las nuevas tecnologías y competencias digitales, a la consideración de los contextos y los temas ambientales, todos ellos ubicados en los principios de Adaptabilidad, Accesibilidad y Aceptabilidad.

En conclusión, podemos afirmar sin temor a equivocarnos que la difusión realizada desde las revistas científicas se constituye en un mecanismo fundamental en los procesos de generación de conocimiento y de calidad académica en tanto ofrecen información sobre el estado del arte y contribuyen con el rol científico y social que inherente a las universidades.

Palabras clave: universidad; ciencia; calidad de la educación; editorial.

Fecha de Recepción: 19-07-2019
Fecha de Aceptación: 27-09-2019
Fecha de Publicación: 05-11-2019 


\section{University, science and context for academic quality: An indispensable relationship in the research processes}

Editorial

Academic quality in universities, understood from teaching, research and linking, implies the four principles or characteristics proposed by the United Nations Organization (UN) in the International Covenant on Economic, Social and Cultural Rights (ICESCR, 1966), these are: Affordability (availability), Accessibility, Adaptability and Acceptability "4 A" (p. 1-10); Specified by Tomasesvky (2004): Rapporteur of the United Nations, expresses that these characteristics or principles refer to the right of persons to and in quality education and to the obligation of the member states of the Covenant to offer it; In this case, we refer to higher education (p. 378). In general terms, the four principles work interrelatedly between the three substantive functions and across the entire university, in order to promote academic quality. This quality refers to the academic offer of education (careers, programs, research and linking projects, continuing education among others) being relevant to the needs of the contexts, to the advancement of science, to the development plans of the country, as well as the characteristics and learning styles of the students, among other variables that contemplate it.

In the Ecuadorian case, Organic Law of Higher Education (LOES, 2010a): it states that from the institutions that govern higher education in the country, attempts have been made to guarantee such quality, to foster the link with society and research in search of the development of the cognitive matrix (arts. 350-351). Thus, the Organic Law of Higher Education (LOES, 2010b): establishes a special article for the issue of relevance, which specifies its meaning and the consideration that universities must have for their offer (art. 107).

Regarding the research topic, the Academic Regime Regulation (RRA, 2019), issued by the Higher Education Council (CES), highlights the 
importance of the research processes and their mandatory academic offer. On the one hand, it gives research an institutional character within the substantive functions and conceives it as: "(...) a creative, systematic and systemic work, based on epistemological debates and environmental needs that enhance scientific knowledge and knowledge, ancestral and intercultural (...)" (art. 4); in literal b; on the other hand, it develops extensively the topic of Formative Research, and defines it in terms of "a process of use and generation of knowledge characterized by the application of conventional research methods, innovation, analysis and validation between peers producing, generally, knowledge of relevance and local, national and / or international validity (...)" (art. 39). This consideration in the RRA, entails the mandatory research training from undergraduate.

As can be seen, the issue of relevance is repetitive, now referred to the generation and application of knowledge. It is in this aspect that we want to mention, briefly, the experience of the Catholic University of Cuenca (UCACUE), which has embraced the Principles of quality " 4 A" of higher education of the United Nations Educational Organization, the Science and Culture (UNESCO) and has done an important job to guide its academic relevance according to the needs of the contexts and advances of science.

In this order and within the framework of a curricular evaluation process applied to its 45 undergraduate courses in its seven (07) Academic Units (in all its headquarters and extensions), UCACUE conducted 39 focus groups with institutions and companies (76 of the public sector and 64 private sector, for a total of 140 institutions) in an unprecedented research in the university. The applied focus group technique allowed, among other things, to gather transcendental information for the adjustment of relevance (in accordance with the principles of Affordability, Adaptability and Acceptability) and the determination of research needs, both in the development of research skills in students, as in specific aspects to be investigated to solve problems of society 
that require new scientific knowledge of a theoretical and methodological nature. The work of analysis in careers, disciplines and subdisciplines still continues given the richness of the information obtained.

Among the results, the one related to the research competencies of the students emerged, there were several elements of necessary intervention highlighted: capacity for observation and analysis, linking theory with practice, comprehensive and critical reading, critical thinking, logical reasoning, creativity, initiative. Likewise, an aspect that emerged both in the competences and in the nature of the problems to be investigated, we refer to the interdisciplinary approach to the phenomena. We can affirm that in $80 \%$ of the focus groups carried out, the participating actors in the context reported on the need to design and execute research, linking projects and even preprofessional practice, from an interdisciplinary perspective given that the solutions proposed from a single discipline They have been partial and not integral.

The results obtained at each headquarters and extension were interesting in terms of the generalities and particularities found in the same career offered in different contexts. For example, in the case of health, in Cañar, urgent intervention is needed in the areas of infant mortality and gastrointestinal problems in rural and indigenous communities; In Macas, research on the presence of HIV in the Shuar population is pressing, which is causing a high mortality rate; On the other hand, in Cuenca the issue of childhood diseases (which had been eradicated) arises as a result of the immigration of families from other countries. In all these cases, research projects and proposals made from interdisciplinary teams with the presence of doctors, nurses, anthropologists, psychologists, social workers and educators are requested. For the Observatory of the Rights of Children and Adolescents (2012): "in the Ecuadorian social context, education is a necessity to train individuals with greater capacities to carry out their personal projects and 
improve their vital conditions" (p. 224).

From these results it is possible to infer that, as regards the aforementioned relevance, the relationship between the university and the contexts becomes a necessity, it is no longer possible for the university to be disconnected from the needs of the environment. On the other hand, as regards the investigative processes, the voices consulted demand us a fundamental relevance, but, necessarily, accompanied by interdisciplinary approaches that account for the complexity of the phenomena in order to deeply know their causes and generate adequate solutions.

With this panorama as a backdrop, we celebrate the edition of this issue of the magazine and we celebrate it because it has been oriented to disseminate results of research experiences that point to the achievement of quality proposed by UNESCO, to the relevance that it poses LOES and the research requirements in the training formulated in the Regulation of Academic Regime, as well as interdisciplinarity and the relationship with the contexts demanded by the actors of the focus groups worked at UCACUE. In this sense, the role of scientific journals in the dissemination of knowledge greatly contributes to the advancement of a science with global / local character and with social and environmental awareness.

Articles referring to the social transformation from the research work of the universities, the role of the teacher in the community service, lines of research and knowledge management are published in this issue (the latter absolutely necessary to be able to respond timely and relevant to the needs of the country's contexts and Policies), the development of science towards its conception from complexity. Are these issues directly related to what is described here. On the other hand, there are articles of interest for the achievement of the quality of education in accordance with the four UNESCO Principles, such as those referring to the role of the university teacher, the use of new technologies and digital competences, to the consideration of 
environmental contexts and issues, all located in the principles of Adaptability, Accessibility and Acceptability.

In conclusion, we can affirm without fear of being mistaken that the dissemination made from the scientific journals constitutes a fundamental mechanism in the processes of knowledge generation and academic quality as they offer information on the state of the art and contribute to the scientific role and social that inherent in universities.

Keywords: university; science; educational quality; publisher.

Date Received: 19-07-2019
Date Acceptance:

27-09-2019
Date Publication: 05-11-2019 


\section{Referencias}

ICESCR (1966). Pacto Internacional de Derechos Económicos, Sociales y

Culturales. Resolución 2200 A (XXI). Nueva York, Estados Unidos: Asamblea General de las Naciones Unidas. Recuperado de: https://www.ohchr.org/sp/professionalinterest/pages/cescr.aspx

LOES (2010). Ley Orgánica de Educación Superior. Quito, Ecuador: Asamblea Nacional.

ODNA (2012). Estado de los derechos de la niñez y la adolescencia en Ecuador 1990-2011. Primera edición, ISBN: 978-9942-9890-0-0. Quito, Ecuador: Observatorio de los Derecho de la Niñez y la Adolescencia, Plan International, Save the Children, UNICEF. Recuperado de: https://www.unicef.org/ecuador/http---www.bibliotecaunicef.org-wpcontent-uploads-2013-11-Edna2011 web.pdf

RRA (2019). Reglamento de Régimen Académico. Quito, Ecuador: Consejo de Educación Superior (CES).

Tomasevski, k. (2004). Indicadores del derecho a la educación. Revista IIDH. Instituto Interamericano de Derechos Humanos, (96), 341-388. México: Universidad Nacional Autónoma de México. Recuperada de: https://revistas-colaboracion.juridicas.unam.mx/index.php/rev-institutointeramericano-dh/article/view/8220/7368 


\section{Rebeca Castellanos Gómez \\ e-mail: rebeca.castellanos@ucacue.edu.ec}

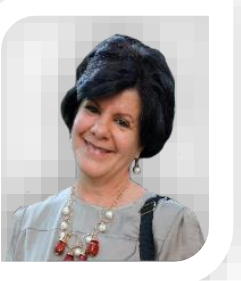

Nacida en Caracas. Venezuela, 28 de diciembre de 1956. Licenciada en Educación, Mención Dificultades de Aprendizaje en la Universidad Nacional Abierta (UNA), Venezuela; Magíster en Gerencia de Recursos Humanos en la Universidad Nacional Experimental de Guayana (UNEG), Venezuela; Doctora en Ciencias Pedagógicas en la Universidad de La Habana (UH), Cuba; Diplomado en Transformación Educativa en Multiversidad Mundo Real (2010), México; Cargos desempeñados: Ecuador: Universidad Católica de Cuenca (UCACUE) como Directora de Principio y Adaptabilidad (actualmente en ejercicio); Jefa de Planificación Académica; profesora-investigadora titular Principal de la Universidad Nacional de Educación (UNAE) en el periodo (2015-2018); Vicerrectora Académica en la Universidad Nacional de Educación (UNAE); Miembro de Comisión Gestora; Directora de Postgrados de la Universidad Nacional Experimental de Guayana (UNEG), Venezuela; Responsable de la Línea de Investigación Formación Docente; Directora-Editora de la Revista Científica Kaleidoscopio (ISSN: 1690-6054); Coordinadora de Doctorado en Ciencias de la Educación; Jefa Departamento de Educación, Humanidades y Artes; Profesora de pregrado (UCACUE-UNAE-UNEG) y postgrado UNEG, y de la Universidad Interamericana de Educación a Distancia de Panamá (UNIEDPA); Autora de libros sobre formación de profesores; Articulista de revistas científicas nacionales e internacionales; Ponente y conferencista de eventos nacionales e internacionales en el área de formación docente y educación.

El contenido de este manuscrito se difunde bajo una Licencia de Creative Commons ReconocimientoNoComercial-Compartirlgual 4.0 Internacional 